\title{
Centromere Protein S
}

National Cancer Institute

\section{Source}

National Cancer Institute. Centromere Protein S. NCI Thesaurus. Code C116622.

Centromere protein $\mathrm{S}(138 \mathrm{aa}, \sim 16 \mathrm{kDa})$ is encoded by the human CENPS gene. This protein is involved in both DNA binding and DNA damage repair. 